\title{
УДК 792.06 \\ КУЛЬТУРНАЯ САМОИДЕНТИФИКАЦИЯ И СОХРАНЕНИЕ СВОЕЙ НАЦИОНАЛЬНОЙ \\ САМОБЫТНОСТИ В ПЕРОД ПОЛОНИЗАЦИИ ЗАПАДНО-БЕЛОРУССКИХ ЗЕМЕЛЬ В 20-40-Х ГОДАХ ХХ ВЕКА (НА ПРИМЕРЕ ТЕАТРАЛЬНОГО ИСКУССТВА)
}

\section{В. И. НАУМОВА}

\section{Брестский государственный технический университет, г. Брест, Беларусь}

Национальная культура белорусского народа формировалась на протяжении нескольких веков и стала симбиозом оригинальных художественных школ, самобытных музыкальных, сценических и литературных произведений, вошедших в золотой фонд мировой культуры. При этом история белорусской культуры пережила много моментов, когда ее пытались нивелировать, не признавали на разных государственных уровнях, а порой и откровенно подвергали различного рода гонениям. Одним из таких сложных для белорусской культуры периодов были 20-40-е годы XX века. И особенно ярко это выразилось на территории так называемых «восточных окраин», которые вошли в состав Польши по Рижскому мирному договору [1].

Национально-культурная политика польских властей того периода была направлена на скорейшее "ополячивание" населения Западной Беларуси, польское государство всячески содействовало распространению и развитию преимущественно польской культуры, активно работало с молодежью, способствовало деятельности различных общественных организаций в области искусства, таких как: Союз народных театров и хоров, Товарищество польского народного театра, Общество поддержки польской сцены и др. Специфичным для данного периода является также распространение передвижных театральных коллективов и других форм художественной самодеятельности.

В этот период польские театры вместе с Министерством вероисповедания и общественного просвещения проводили большую работу с молодежью. Так, в декабре 1932 г. началась работа по организации молодежного театра при Виленском городском театре. При этом часто городские театры курировали школьные драмкружки, а также молодежные и школьные театры, особо популярные в то время в Польше. Большую идеологическую нагрузку брали на себя так называемые Попечительные советы, которые занимались подготовкой идеологически выверенного театрального репертуара. Например, в 1932 г. в ведомственном еженедельнике попечительного совета Виленского школьного округа был опубликован материал «О надлежащем использовании театра в образовательных целях в школе», в котором давались рекомендации по целенаправленному просмотру спектаклей с последующим обсуждением его с актерами и с заданием ученикам написать рецензию или сочинение по увиденному. Таким образом, учителя могли постоянно контролировать политические и идеологические устремления подрастающего поколения.

Еще одной особенностью данного периода является открытие во многих местечках Западной Беларуси польских культурно-просветительских центров, так, в частности, широкую известность приобрел «Союз деревенской молодежи», который стремился к объединению всей молодежи и ее идейному просвещению в духе польской идеологии [4].

Между тем белорусская культура, как и культура других национальностей, населявших данные территории, находилась фактически под запретом у официальной власти. Именно в данный период белорусское театральное искусство, зародившееся еще в начале XX века и имевшее свой самобытный и богатый сценический опыт, было лишено возможности самовыражения и встречи с публикой, т. к. в течение длительного времени белорусский народ не имел своего профессионального театра на территории Западной Беларуси. При этом уже с первых дней существования в составе Польши представители 
белорусской интеллигенции предпринимали попытки создания постоянно действующего, стационарного белорусского театра. Уже в начале 1921 г. Ф. Олехнович организовал передвижную театральную труппу, с которой показал несколько спектаклей. А в самом Вильно в сентябре 1921 г. Л. Родиевич, М. Красинский и А. Кончевский организовали музыкально-драматический кружок, который начал свою деятельность с постановки пьесы Я. Купалы «На папасе» [2, с. 123]. В 1922 г., после присоединения к ним А. Михалевича, на базе данного кружка была организована Белорусская драматическая мастерская. В состав этой творческой театральной студии входили ученики и преподаватели виленской белорусской гимназии, а также студенты университета и представители белорусской интеллигенции. Однако польская администрация постоянно мешала деятельности этой студии. Только в начале 1924 г. Белорусская драматическая мастерская добилась своей легализации в качестве одноименного товарищества. Основатели студии были ориентированы на инсценировку белорусской и иностранной драматургии, создание передвижного театра для сельского населения, подготовку актерских кадров. Сценические постановки белорусской драматической мастерской представляли собой синтез драматических произведений, выступлений хора, танцевальной группы, декламации и других художественных элементов [2, с. 123]. Для творческой молодежи проводились лекции на актуальные темы белорусского театрального и музыкального искусства. Среди представляемых произведений особенно популярными были: «Раскиданное гнездо», Я. Купалы, «В зимний вечер» Э. Ожешко, «Лес шумит» В. Короленко, «Последнее свидание» В. Голубка, а также водевили Л. Родиевича, такие как «Смущенный Савка», «Посланец», «Богатый и бедный» и др. На сцене также ставились пьесы Ф. Олехновича, который в начале 1924 г. был приглашен для постановки спектаклей, а в последующем был избран директором Белорусской драматической мастерской.

Важную роль в жизни Западной Беларуси в 1920-1930-е гг. играло также Товарищество белорусской школы (ТБШ). Эта массовая культурно-просветительная организация, созданная в 1921 г., к началу 1930-х гг. насчитывала около 500 кружков и до 30 тыс. активистов. Организация боролась за грамотность населения, за открытие новых и сохранение существующих белорусских школ, создавала клубы, библиотеки, избы-читальни, организовывала художественную самодеятельность, народные хоры, занималась изданием литературы на белорусском языке. Активно работали среди населения драматические кружки, организованные местными отделами ТБШ. При этом любительские спектакли и концерты превращались в настоящие праздники, были своеобразной формой протеста против полонизации. Белорусские зрители постоянно выступали в защиту своей национальной культуры, требуя ее свободного развития, а полиция постоянно арестовывала руководителей художественной самодеятельности и запрещала спектакли.

В 1930-е гг. идею организации профессионального театра пыталось провести в жизнь «Общество белорусского просвещения» [3, с. 56]. Под руководством А. Михалевича обществом была организована белорусская театральная труппа. Причем руководители труппы отмечали, что власти довольно лояльно относились к их организации. Вероятно, это было связано с тем, что само «Общество белорусского просвещения» заявляло о необходимости мирного диалога с правительством Ю. Пилсудского по политическим вопросам. Участники этих драмкружков не вводили в свой репертуар социально значимых произведений, которые бы затрагивали проблемы современной жизни, и ставили на белорусском языке только легкие комедии или мелодраматические пьесы. Этим, в первую очередь, отличались драмкружки, которые находились под влиянием партии «Белорусская христианская демократия» (БХД) [5, с. 65]. Создавались такие кружки, как правило, при католических приходах, а организаторами и руководителями в них обычно выступали католические священники. 
Особое место в общенародном движении за национальное освобождение, а в его рамках - за сохраненные белорусской культуры, принадлежало студентам. Творческие встречи, дискуссии, вечера сопровождались постановкой пьес, декламацией стихов. Деятельность Студенческой организаций была направлена главным образом на воспитание чувства национального достоинства белорусов. Характерным примером является Белорусский Студенческой союз Виленского университета, который существовал с 1920 г. до времени его закрытия в 1939 г. Деятельность этой организации приносила много забот польским властям, т.к. Союз вел активную просветительскую работу, в основу которой было положено чтение лекций различной направленности: «Белорусы как народ», «Мы и наше Отечество», «Белорусы в Польше», «Трагедия белорусской интеллигенции», «Значение театра для общества», «Необходимость просвещения в деревне» и др.

Помимо белорусов о сохранении своей национальной культуры заботились и представители других национальностей. И в данный период достаточно бурно развивалось еврейское искусство и музыка. В частности, вторыми по численности и популярности после польских театров были еврейские. Уже в 1920 г. начало свою деятельность Виленское еврейское театральное общество, которое занималось открытием театральных студий, изданием газет, журналов, организацией лекций, докладов по развитию еврейского театрального искусства. По его инициативе были созданы драматический, камерный театр, а в 1921 г. появился объединенный еврейский театр драмы и оперетты. С 1922 г. в Вильно действовало Товарищесво поддержки еврейской культуры, которое имело секции литературы, музыки, оперного и пластичного искусства. Именно это товарищество явилось инициатором создания в конце 1924 г. Еврейского музыкального института, который получил статус госсударственной консерватории - единственный во всей Европе с преподаванием на идиш. Данное учреждение было очень популярно далеко за пределами Польши, причем уважением и почетом пользовался не только талантливый пианист и директор еврейского музыкального института Р. Рубинштейн, но и многие его талантливые педагоги : преподаватель фортепиано и вокала Т. Гиршович, Ф. Кревер, Х. Дуговская, Э. Игдал, Ю. Кружанко и др. В 1935 г. в одном только Вильнюсе действовали 15 еврейских театральных коллективов, которые ставили классические и современные пьесы.

Одним из наиболее оригинальных еврейских культурных учреждений был театр марионеток «Майдим» в Вильно. Большая часть артистов данного театра были любителями, энтузиастами из разных слоев населения, которые получили театральную подготовку в драмкружках. Основным девизом данной труппы был возглас: «Посмеемся!»- и они, в самом деле, оправдывали свой девиз, т.к. комические и сатирические сценки этого театра пользовались большим успехом у зрителей.

Своеобразной и достаточно активной была также культурная жизнь русского населения. В 1922 г. в Варшеве было создано Русское благотворительное общество, которое имело право создавать и содержать русские гимназии, а также проводить различные культурно-массовые мероприятия. На территории Западной Беларуси к середине 1930-х гг. были созданы отделы РБО в таких городах как Брест, Пинск, Лунинец, Гродно, Новогрудок, Барановичи, Столбцы. Именно при них объединялась местная русская интеллигенция и создавались литературные, театральные кружки, а также другие творческие объединения. Основная деятельность данных групп зависела от колличества русского населения в данной местности. Так русское общество в Бресте в основном заботилось о содержании русской гимназии, в которой при активной поддержке РБО работал кружок любителей драммы под руководством П. Алексеева. Кружок ставил произведения русских классиков : А. С. Пушкина, А. Н. Островского и др. Их постановки отличались высоким уровнем профессионалного мастерства. Драматическая секция подотдела часто оказывала помощь русским самодеятельным театральным объединениям брестского повета. Брестский отдел 
РБО также активно сотрудничал с обществом любителей церковного пения, основанным настоятелем Николаевской братской церкви С. Жуковским, которое несколько раз в год проводило хоровые концерты [6, с. 205].

Отдел РБО в Пинске, организованный в 1925 г., занимался в основном содержанием русской 7-ми классной реальной гимназии, а после введения запрета на ее деятельность в 1928 г., организовывал различные культурные мероприятия, доходы от которых шли на благотворительность. В середине 1931 г. им был создан молодежный кружок под руководством Д. Майкова, в рамках которого действовали музыкальная, литературная и драматическая секции.

Также, благодаря поддержке русского благотворительного общества, на территории Западной Беларуси часто проходили гастроли русских театральных трупп из Варшавы и Вильно. В этот период здесь проходили гастроли русского драматического театра под руководством Е. Гагаринова, Виленского театра русской драмы (рук. Ю. Скипетров), русского театра-кабаре «Эльдорадо» (рук. Ю. Гасюк) и др. Однако в конце 1927 г. Полесский воевода Я. Крагельский приказал повятовым старостам не разрешать постановки русских передвижных театральных трупп, особенно там, где представления на русском языке могли «разбудить национальный антагонизм» [6, с. 206].

Одним из наиболее активных театральных коллективов Виленского русского общества была литературно-артистическая секция, которая действовала с начала 1922 г. первоначально как Русский литературно-артистический кружок при читальне ВРО. Еженедельно ими устраивались литературные вечера в столовой Русского Общества, среди активных участников этой секции были : председатель В. А. Кузьмицкий, А. А. Авлов (Кондуралов), И. Л. Агнев, Д. Д. Бохан, Д. Г. Гарб, В. А. Калускевич, 3. К. Липкин, Н. А. Лозино-Лозинская, К. И. Оленин, О. И. Пилецкий, В. Н. Селиванов, 3. А. Семенова, Т. А. Соколова, К. К. Французович, Н. М. Эйгес, Л. Л. Белевский. На еженедельных литературно-драматических четвергах читались произведения местных и приезжих авторов, отмечались юбилейные и памятные даты русской литературы (годовщины смерти Н. А. Некрасова, А. Н. Островского, рождения А. С. Пушкина и т. п.), проводились авторские вечера поэтов, обсуждались доклады (напр., В. В. Богдановича о философии Бердяева); как правило, музыкальная программа проходила во втором отделении вечеров. Осенью 1932 г. председателем стал Д. Д. Бохан, и деятельность секции оживилась. Проводились конкурсы стихотворений, рассказов и драматических произведений. Главной формой деятельности остались вечера по четвергам. Часть вечеров была посвящена выступлениям поэтов, реже прозаиков, с музыкальными выступлениями и драматическими постановками в концертном отделении. Активисты Литературно-артистической секции участвовали также в знаменитых польских "литературных средах".

В 1924 г. Министерство внутренних дел Польши сообщило Полесскому воеводе о том, что отказала П. Трельскому в концессии на показы русского передвижного театра, ссылаясь на то, что терпимость, а тем более поддержка российского театра в восточных «окраинах» не желательна, поскольку пропаганда русской культуры не способствует интересам польского государства. Примерно в том же направлении шла переписка между Министерством внутренних дел и Полесским воеводством о разрешении на приезд из Волыни русской труппы под руководством Д. Маркова.

Интерес представляет документ 1934 г., в котором отдел безопасности Виленского воеводства просит старост не создавать препятствий русским артистам для выезда на работу в СССР [5, с. 64]. Именно это, по мнению польских чиновников, позволило постепенно ликвидировать русские драматические кружки на территории северо- 
восточных воеводств. Такие же меры принимались и по отношению к представителям белорусских театральных кругов.

Защита русской культуры и просвещения являлась одним из основных направлений деятельности Русского народного объединения, созданного М. Серебрянниковым в Варшаве в 1926 г. В декабре 1926 г. РНО организовало в Бресте Полесский клуб, который стал центром русской интеллегенции.

Не смотря на разность идейно-политических ориентаций, западно-белорусские культурно-просветительские учреждения достаточно решительно отстаивали в 1920-1930-е гг. свои национальные интересы, а также выступали против полонизации. ТБШ, БИГиК превратились в массовые организации, имели широкую поддержку жителей Западной Беларуси. Однако во второй половине 1930-х гг. все ранее организованные формы защиты национальной культуры были подавлены польскими властями. Самоотверженная работа народных энтузиастов сценического мастерства в условиях, когда полонизация в так называемых «Восточных окраинах» возводилась в ранг государственной политики, была настоящим подвигом.

\section{Литература}

1. Рижский мирный договор. Текст [Электронный ресурс]. - 2004. - Режим доступа : https://inosmi.by/2015/05/26/rizhskij-traktat-polnyj-tekst/ - Дата доступа : 02.09.2020.

2. Вабішэвіч, А. М. Нацыянальна-культурнае жыццё Заходняй Беларусі (1921-1939) Брэст : БрдУ, 1997. - 319 с.

3. Вабішэвіч, А. М. Асвета ў Заходняй Беларусі (1921-1939) / А. М. Вабішэвіч. - Брэст : БрДУ, 2004. - 115 с.

4. Царюк, Н. А. Просветительская деятельность польских театров на территории Западной Белоруссии в межвоенный период. [Электронный ресурс] - 2010. - Режим доступа : http://www.elib.bsu.by/bitstream/123456789/40726/1/19-22.pdf - Дата доступа : 15.09.2020.

5. Царук, Н. А. Тэатральная дзейнасць у Заходняй Беларусі / Н. А. Царук // Беларускі гістарычны часопіс. - 2002. - № 5. - С. 60-67.

В статье говорится о самоотверженной борьбе против полонизации белорусской культуры и культуры других народов, заселявших "восточные окраины" в 20-40-х годах XX века.

The article talks about the selfless struggle against the polonization of the Belarusian culture and the culture of other peoples inhabiting the "eastern outskirts" in the 20-40s of the XX century. 